ESJ Humanities

\title{
Benin Influence on Isua Chieftaincy Titles: A Historical Exploration
}

\author{
Olusanya Faboyede, PhD \\ Department of History \& International Studies, \\ Adekunle Ajasin University, Akungba-Akoko, Ondo State, Nigeria
}

Doi:10.19044/esj.2022.v18n7p53

Submitted: 04 November 2021

Accepted: 07 February 2022

Published: 28 February 2022
Copyright 2022 Author(s)

Under Creative Commons BY-NC-ND

4.0 OPEN ACCESS

Cite As:

Faboyede O. (2022). Benin Influence on Isua Chieftaincy Titles: A Historical Exploration. European Scientific Journal, ESJ, 18 (7), 53. https://doi.org/10.19044/esj.2022.v18n7p53

\section{Abstract}

The influence of geography and migration on group relations in the periphery border areas of northeastern Yorubaland with the Edo-speaking people cannot be over-emphasised. Migration of people profoundly influenced cultural diffusion in towns and villages in Yorubaland, including Isua in Akokoland. In spite of cultural influence of the Benin kingdom on the people of border communities in the frontier zone of northeastern Yorubaland, the available earlier scholarly works mainly focused on how cultural evolution started in Ile-Ife, and the effects on towns and villages in the forest zone of Yorubaland without examining Benin's influence on Isua chieftaincy titles in the pre-colonial period. This omission has created a vacuum in Yoruba historiography. This is the gap this study intends to fill. The study adopts the narrative approach and critical evaluation of data collected in order to discuss Benin influence on Isua chieftaincy titles in pre-colonial period.

Keywords: Benin, Isua, chieftaincy, identity, migration

\section{Introduction}

There is a great similarity between the traditional worldviews of the people of Benin and Isua Akoko of Ondo State, especially in the area of chieftaincy titles. This may not be unconnected with the fact that the Benin kingdom exerted a strong influence on and domination over the people of Akokoland. It is, therefore, important to discuss Benin historical influence on 
the chieftaincy titles of Isua community. Benin influence was felt in every community on the Edo-Yoruba border area, particularly border communities in northeastern Yorubaland. It is desirable in this study to make a historical study of Benin influence on Isua chieftaincy titles by putting forward a plausible argument, leaning on oral traditions that will be complemented with secondary sources. In the pre-literate society, oral traditions are very useful to reconstruct local history (Oguntomisin, ed. 2006: 4\&5) \& Adediran, 1989:114).

Much has been written about border communities in Edo and northeastern Yorubaland, including Isua (Olukoju et.al, 2003), which shed more light on the historical antecedent and link with Benin kingdom. However, comprehensive works on Benin influence on Isua chieftaincy titles had suffered the fate of a history of neglect by historians, except Akomolafe who glossed over it in his work (Akomolafe, 1976:5\&6). The task of the present study is to cover eastern and northeastern parts of Yorubaland, particularly the Akoko section of Isua and Benin kingdom. The justification for this study is to examine the contribution of Isua cultural history to Yoruba historiography, by analysing the Benin influence on Isua chieftaincy titles.

The study is divided into seven parts. First, is the introductory section, the second part discusses tradition of history and geography of Isua community, the third section analyses Isua historical connection with the Benin kingdom, the fourth part examines the evolution of Isua chieftaincy titles and its equivalence in Benin kingdom, the fifth part makes a comparison of the structure, functions and duties of the selected chieftaincy titles in Isua with Benin kingdom, and the sixth part makes a critique of Benin-Isua relations. The seventh part concludes the discussion of the study.

\section{Method and Sources}

The study employs narrative approach to make use of both secondary and primary sources; however, there is a growing new trend towards historical studies in modern historiography. The bibliography demonstrates the variety of sources used in this study. The era of narrative accounts (reportorial history) is coming to a close and giving place to analytical research method and reinterpretation of source materials with the use of secondary sources that are available in texts on chieftaincy affairs and pre-colonial Benin diplomatic relations with Isua people andarticles in journals, while primary sources are archival materials, internet sources and interviews collected at various times between 2017 and 2018 from local historians. The use of oral materials constituted an integral part in preserving the traditions, socio-political institutions, folklores and proverbs of the pre-literate societies in Benin kingdom and in Isua community. As a result of the usefulness of oral sources in the historical reconstruction, this study shall make use of historical 
information from the available materials, in spite of its being susceptible to distortions, that will be cross-checked with the evidence obtained from oral history in the places of setting.

In spite of the limitations of oral sources like: timelessness, short memories and falsification of facts, personal pieces of information were still useful in this study. My findings encouraged me to tirelessly work on this study. The archival materials used in this study were obtained from the National Archives in Ibadan and the files analysed contained subject papers, such as intelligence reports on chieftaincy affairs in Isualand and Government papers and court records. The archival materials are limited in events that were biased of colonial official views in contrast the view of the indigenous people in the pre-colonial period. Notwithstanding the problem of objectivity, posed with the adoption of archival materials, it was able to provide another way to reconstruct the history of the pre-literate people in the $21^{\text {st }}$ century. In the light of the above, the study was able to cross-check every document against the other sources, in order to attain the purpose of embarking on this study.

\section{Traditions of Origin and Geographical Description of Isua}

Isua was an ancient town, prior to its dominance by Benin migrants from Benin kingdom (Oyolola, 2010:2). According to Isua mythology, the word, Isua, has been given etymological interpretation. Etymologically, Isua can be a derivative of Isi-Uhami ${ }^{l}$. The etymology of Isua was supported by ehanise or egirase (panegyric). The panegyric goes thus:

\section{Isua Omoduragba \\ Evi ki bi a vho kuwa vie vho \\ Eno shivie, mosimiri}

\section{Imonovie duduka}

Eva dogiri

Eva ki bi avho kuwa vie vho

Translation: Isua people that gods answer their prayers

Those that were not born there are willing

Those that break palm kernel and eat the shaft

The king's children

Great people from Edo Benin

That people wish they are one of them. ${ }^{2}$

\footnotetext{
${ }^{1}$ Interview held with Eunice Agbailu, 70 years at odovie (Palace) Okiko quarters, she was interviewed on $5^{\text {th }}$ June, 2018.

${ }^{2}$ Ibid.
} 
The above etymology depicted and lent support to Benin migrants' migration story from Benin kingdom to Isua community. The process of migration began due to succession disputes between Prince Innih and his stepbrother, Ozure. While at Isua, Prince Innih, the leader of the Benin migrants conquered the people of Upala and Osumu, the acclaimed direct descendants from Ile-Ife. Prince Innih established his authority over his hosts and assimilated them into Benin culture (Oyolola, 2010: 2 \& 7). He introduced monarchical system of government, based on the principle of primogeniture, the product of Benin chieftaincy institution that was brought by Prince Innih (Ibid. p.27).

The traditions of origin of Isua people rested on two fundamental historical sources: Benin Kingdom and Ile-Ife. There are two different versions of migration story of Benin migrants to Isua community. First, tradition claimed that Prince Innih, the leader of Benin migrants in Isua claimed Benin ancestry, which evolved in Benin. It was further claimed that Prince Innih and his group overran Upala and Osumu people (the acclaimed aboriginal in Isua community) and he reigned over them between 1715 and $1725^{3}$. The first settlers were merged by Prince Innih to found Isua as his new kingdom. History asserted that the Benin migrants walked through the forest across Benin kingdom to the northeastern region of Yorubaland, in search of strategic routes for commercial purpose to link with the traders from Ibadan, Ekiti and other parts of Akokoland, particularly those along Isua axis (Akintoye, 1971: 1\&2, Ojo, 2003: 111).

The second version claimed that Prince Innih migrated directly from Benin, and stayed at Ekho ${ }^{4}$ for a while, before he moved and settled in Isua. Similarly, Eweka (1992:30 \& 122) claimed that Isua was one of the associated villages of Benin kingdom. In examining Benin's imperialism and sphere of influence in northeastern Yorubaland, Egharevba (1968: 1-2) also attested to robust Benin's relationship with Isua during Ogiso dynasty. In the process of state formation, Ajiboro asserted that Prince Innih was unanimously accepted to be the overall king in Isua without much resistance ${ }^{5}$.

After the conquest, Prince Innih consolidated his reign as the first Olisua of Isua, the paramount ruler of Isualand (ovie nadi Uhami) cited by Oyolola (2010:3). He adopted chieftaincy titles that were replica of Benin

\footnotetext{
${ }^{3}$ Prior to Prince Innih's settlement with Upala and Osumu people, it was observed that Isua was occupied by typical Yoruba people; the Okien, Ozoi, Uloo and Igbakunu who claimed direct migration from Ile-Ife, before their conquest by Prince Innih. Aftersettlement, the Benin Prince, Innih restructured their chieftaincy institutions in line with Benin indigenous political culture. The Ife (Yoruba) culture, seemingly suffered setback due to the strong cultural influence of Benin migrants on the people of Isua. (See Oyolola, p.2).

${ }^{4}$ Ekho is situated along Ibillo section on the boundary between Isua and Edo communities in eastern part of the present Edo state.

${ }^{5}$ Ajiboro interview cited.
} 
chieftaincy institution in his new settlement at Isua. It is important to mention that before the conquest of Isua, the people of Upala and Osumu operated traditional democratic set up, which was dismantled by Prince Innih and his followers. The former system of governance was replaced with superior political institution that was more depended on him as the $O b a$ and members of his ruling family ${ }^{6}$. Notwithstanding the political challenge faced by Prince Innih, he took authority over indigenous people of Isua and adopted Benin chieftaincy titles of Olisa, Osere and Ojomo with Benin equivalent (Egharevba, 1968:76-79) that shall be discussed in this study. He adopted the chieftaincy titles to promote the culture of his forefathers and preservation of Benin heritage. Benin historical connection was very deep in Isua community due to its former affinity with Benin kingdom before the chieftaincy crises.

On the history of migration,(Akomolafe,1976:6716,Ilesanmi,1964:3, Ojo, 1966:104\&115 and Smailes,1953:54) mentioned the factors that determined effective direct contact and relationship with the first settlers in other parts of Yorubaland. In the case of Isua, the story of migration showed long time historical connection with the people of Benin. Akintoye also reiterated this, when he mentioned that Isua had long contact with Benin kingdom in the past, through trading activities (Akintoye: 9).

The geography of Isua was (and is) still situated at the periphery of Yorubaland language unit like other Akoko towns and villages in the northeast (Obayemi Eds. 1980: 202) and Isua language is Edoid, despite its location in Ondo state. The agrarian nature of Isualand and its proximity to Benin

${ }^{6}$ The assertion here was not as fanciful as it was appeared because there were extant myths from Okien, Ozoi, Uloo and Igbakunu, the groups of people that formed Odi Ruling family. However, their place of origin and migration was not mentioned in Oyolola's text. Oyolola mainly reiterated the defeat they suffered from Prince Innih's imperialism and domination over them before they were absorbed into Benin culture. Be that as it may, the Ile-Ife migrants were referred to as outsiders that revolutionised Isua ancient history. Consequently, in his study of Isua history, Oyolola also offered contextual view about the earliest history and migration of the people of Isua. Thus, his explanation of the origin and palace organisation of the indigenous people of Isua during Innih's reign was patriotic. No doubt, historical flaws were inherent in his discussion. His story telling was evasive and reportorial and, it had no place in re-interpretation of the available source materials. He situated Isua history comparatively with the parallel source materials with politically biased traditional rulers and community leaders who failed to carefully seek historical facts from knowledge or wisdom of (Yoruba) history that subjected Oyolola's study to be more useful in the compilation of historical study. The interpretation sounds rather convenient, but the new revisionism in Isua history was an evidence of political freedom of no subservience to Benin imperialism. In contrast, Oduduwa was the acclaimed ancestor of Odi Ruling House; as it was claimed among the ruling Houses in Yorubaland. On that background, it does not mean that Oduduwa was the ancestor of all Yoruba ruling Houses and people. People had settled and lived in Ile-Ife and other parts of Yorubaland before the arrival of Oduduwa in Ile-Ife. In that case, the history of dynasty should not be confused with the history of the people (See Oyolola, pp. $2 \& 3$, 15\&27, Akomolafe, p. 7, Erediauwa, pp. 209-210 \& Akinruntan, F.E.O, pp. 1cf). 
kingdom influenced the dialect spoken among the people of Isua community ${ }^{7}$. Isua is located on plain savannah land in the eastern part of the forest zone of northeastern Yorubaland. The town is bordered on the non-Yoruba Edo kingdom and is one of the foremost border towns in Akoko South East Local Government Area in Akokoland of the present Ondo state. Akoko is a vast land lying between 50 and 60 east of the Greenwich Meridian and Latitude 70 and 71/4 north of the Equator. Akoko is composed of descent groups of different sizes that agreed to live together in enclave compound. The people of Isua community contained immigrants in order of arrival like Upala, Osumu (Isua-Oke), the Ife migrants, while Izo, Okua, Eze, Irobo, Ereva, Odovie, Oyara, Ahinokunu and Izo Oshami are migrants that left Benin in Benin kingdom in $1715^{8}$. The community shared common boundary with AkokoEdo along Ose River in the eastern side of Ikiran in the present Edo state. In the classification of the peoples of Akoko, Isua was classified among BeninAkokos. The dialect spoken in Isua showed evidence of inter-group relations and kinship association with the Benin people in the past (Akintoye, 1969:540, Beeley, 1932: paras. 273, 62 - 63, Ogidan, 2013:ix, Oyolola:2).

\section{Isua Historical Connection with Benin}

There was historical evidence aboutthe place of Benin in early dynastic history of Isua, which can be traced to the problem of chieftaincy tussles among Princes in Benin. To examine Benin's replica of chieftaincy titles in Isua chieftaincy structure, it is necessary to discuss Isua connection with Benin. The similarity in chieftaincy titles espoused Isua historical link with Benin during the old Benin Empire and those chieftaincy titles with Benin cultural heritage and name accompanied Prince Innih on his migration to Isua and the titles were retained as titles in Isua chieftaincy structure or institution.

The genesis of the evolution of chieftaincy titles in Isua can be associated with the power conflict that started in Benin. Oral history acclaimed that if the Oba's (king's) wives were pregnant, they lived outside the palace, and the first among whose birth was announced to the public would be considered as the eldest male child among the male children that were born the same day, and he would be the next king in the community. As a result, Ozure, Prince Innih's step-brother, became the king in 1713, with the title Ozuere (Oyolola: 19 \& 20). However, problems of seniority and power tussle began between them, because the selection was against the primogeniture system of political structure. In accordance to customs and traditions of the

\footnotetext{
${ }^{7}$ Interview with Dr. (Mrs.) K.V. Olugbemi, Lecturer, Department of History \& International Studies, Adekunle Ajasin University, Akungba-Akoko, Ondo, Nigeria, 09 -02- 2017.

${ }^{8}$ Interview with Alonge Dominic, (the Atunluse of Isualand), L/11, Idofin Quarter, IsuaAkoko, 10 April, 2016.
} 
Benin kingdom, the eldest male son usually succeeded and reigned after his father (Ibid. pp. 19-20).

Due to the potency of tradition, Prince Innih was not accorded the paraphernalia of authority to reign over his people in Benin. His inability to occupy the throne of his ancestors influenced his migration, which took him through places like Ekpedo, Idoani, Sosan, among others, before he established a new kingdom in Isua (Ibid. pp. 20-25).

\section{Evolution of Isua Chieftaincy Titles and their Benin Equivalence}

This part discusses chieftaincy titles and its effects on the growth, cohesion and relations between Isua and Benin people. The evolution of Benin resemblance of chieftaincy titles started in Isua after Prince Innih conquered the first settlers in Isua and became the first Olisua, the king of Isua (Ibid. p.3). He was able to establish his reign because Upala and Osumu had a relaxed policy towards the Benin migrants. The indigenous people related with the Benin migrants on good terms by allowing them to own land and built houses. Also, Prince Innih used his military might with sophisticated weapons he obtained from the Dutch and Portuguese slave traders in Benin kingdom to consolidate his authority over the people of Isualand (Ibid.p. 3). He structured his kingdom into chieftaincy type of political institution for easy and better administration. The title men were graded in order of importance. The acquisition, extension and development of Isua chieftaincy titles started during the reign of $\mathrm{Oba}$ Oyolola II (the second) due to his acquisition of western education and exposure. As earlier stated, he had a-well structured chieftaincy system in line with Benin chieftaincy structure of primogeniture to reflect the cultural institution of his forefathers.

Isualand became a strategic centre of trading activities, organised by the Ekhengbo traders (Olukoju, 2003: 2) mentioned association that traded for the Oba of Benin along Akure trade routes to Ekiti, including Akoko towns and villages (Forde \& Kabbery ed, 1967:6, Egharevba:27-34, Akintoye:539553). The Benin kingdom enjoyed increase in commercial relations in Akoko area, due to the defeat suffered by Nupe warlords from Ibadan onslaught, which provided a great opportunity for Benin trading expansion to non-Edo speaking communities in Yorubaland. Similarly, Ojo claimed (2003, p. 14) that Benin (Ekhengbo) traders were prosperous due to their ability to dominate commercial activities around Ekiti-Akoko area of the forest zone of Yorubaland.

To sustain their victory, the Ekhengbo traders and their patron ( $\mathrm{Oba}$ of Benin) cleverly established major trade routes that linked Isua from Benin routes to strategic villages, such as Ikare, Arigidi, Ogbagi with northwestern Yoruba in Ekiti region (Saba in ed. P.12). The economic relationship was prosperous as a result of feasibility of the caravan routes, which enabled 
transportation of agricultural goods like grains, kolanuts, locust beans, tobacco, cotton from the vassal states to Benin kingdom (Ibid. p. 12). The distributions of the local goods were done by traders under the protection of market guilds and trade associations.

Economic organisation and transaction were another potential for maintaining cultural relations with Isua community. The conducive environment provided better opportunities for Isua and Benin people to engage in agriculture and economic activities, which further enhanced socio-cultural integration. Consequently, the $\mathrm{Oba}$ of Benin established hegemony over the conquered territories, which were created under the Balekale (consuls); cited in (Akintoye, pp. 25). The people of Isua were eventually assimilated into the Benin custom of chieftaincy tittles. Through this cultural assimilation, the Benin political and commercial elites, in collaboration with Isua traditional elites, were able to adopt and retain some Benin chieftaincy titles, as discussed in this study (Akomolafe: 6).

With the end of Benin imperialism, as a result of the advent of colonial rule, the aftermath was very decisive on the political history of Isua. By implication, there was no kingmaker in Isua as it had been in Benin kingdom, because the king was born and not made (Igbafe, 1979: 2 \& Eharevba: 40). There were (and are still) chiefs who supervised the coronation of the new $O b a$ with the institutional law, which revolved around primogeniture system. The primogeniture system of selecting and appointing a new king $(\mathrm{Oba})$ in Benin kingdom was (and is still) in practice in Isualand (Ondo state of Nigeria: 1999, paras. 1.3.9 \& Edo, 2001:3. See footnoting of p.1). The Benin influence was very unique in the preservation of the concepts (values) of chieftaincy titles.

\section{The Chieftaincy Structure, Functions and Duties of the Chieftains}

This section discusses the structure, functions and duties of the selected chieftaincy titles in this study. Due to subjugation of the people of Upala and Osumu quarters by Benin migrants, Prince Innih, their leader, introduced new system of Benin type of administration. Given the radical nature of the political organisation or the transferred system of administration, Prince Innih was drawn to the platform of administrative politics. The change took place to ensure continuity in Benin chieftaincy culture. Prince Innih, thus, established Benin chieftaincy ties with Upala and Osumu people (the autochthones) in Isualand. After migration from Benin, the Benin migrants were more enriched in Benin culture and kingship emblems in their lineage structure. The restructuring was very significant on the descent groups (Lloyd, 1962: 54-57 \& Olomola, 1978\&1979: 26-58). The Benin migrants shared relationship with indigenous settlers in Isualand and they experienced centralisation system of ascendancy. 
The main scope of this study, as demonstrated in Akomolafe's p.5, is to emphasise that the features of Benin cultural relics and symbols on Isua chieftaincy institution cannot be glossed over in this present study. The chieftaincy titles can be categorised into royal chief, noble chief, religious chief and common chief. In that context, the following chieftaincy titles, Olisa, Osere and Ojomo in Isualand were equivalent to Oliha, Esere and Ezomo in Benin kingdom. As indicated above, the chieftaincy titles were pronounced and spelt in Benin dialectal variations. This was evident in Isua and Benin historical relations during the pre-colonial period.

The etymology of Chief Olisa was derived from Benin kingdom and adopted to Isua chieftaincy system in order to preserve Benin culture (Egharevba:1-6, Ajayi \& Crowder: 251). In Benin, Oliha was one of the seven councilors among the kingmakers known as Uzama (Nihinron) as mentioned in (Edo, p.3). Chief Oliha performed the role of guidance at the kingdom shrines. According to Benin political history, Oliha was (and is still) the leader of Uzama Chiefs that jointly ruled Benin kingdom with the Oba (Erediuwa: p. 214). While in Isua, Chief Olisa was a quarter chief in Everi quarter in IsuaOke. According to Alonge, the title of Chief Olisa was adopted in Isua to the eldest male child before Prince Innih's initiation and coronation in Isualand ${ }^{9}$. $\mathrm{He}$ was one of the prime movers among the traditional chiefs who took decisions in his quarter on behalf of the Olisua, the paramount king. He was also concerned about the socio-cultural activities and development of Everi quarter ${ }^{10}$. In line with indigenous political set up in Isua, Chief Olisa enjoyed great respect of his people. He was (and is still) in charge of the ancient cultural activities, which defined their existence as a people.

In accordance to the native law and custom, Osere chieftaincy title originated from Izo quarter in Isua and his selection was usually made from the male descent group before he was presented to Olisua for approval (WSN paper: p. 63). Osere chieftaincy title was introduced in Isua during the reign of Oba Agberuwa, who reigned between 1725 and 1745 (Ogidan: 17). Chief Osere was one of the quarter chiefs. He was in charge of the activities of the people of Izo quarter. He attained the status for being a member of the titled family. The chief performed the role of sage in Isua community. Chief Osere held regular meetings with his people and continued in owing allegiance to the Monarch. He was always involved in mediating on important issues that were of common interest in the community. He was (and is still) one of the decisionmaking chiefs in the community. In the olden days, Chief Osere was in charge of civil matters like violence, theft, divorce, among others (Beeley: paras. 103). According to Oguntomisin, the political structure in Yorubaland,

\footnotetext{
${ }^{9}$ Interview with Alonge Dominic cited.

${ }^{10}$ Ibid.
} 
including the chieftaincy system in Isua, was well-arranged (Oguntomisin: p.3). In Benin equivalent, Chief Esere was from the house of Iwebo. In the Benin chieftaincy structure, Chief Esere was an individual title that was created by $O b a$ Ozolua around 1481 AD. It was created to represent the Oba at important occasions, particularly during the coronation day (Igbafe: 6).

The name, Chief Ojomo, originated from Benin kingdom and was institutionalised in Isualand. Chief Ojomo was a honourary chief who was not in control of any quarter in Isua. Every quarter in Isua had its own traditional chief, and assisted the Olisua in co-ordinating his subjects. He was an astute administrator and very diplomatic in performing his functions. He controlled social disorder in the community. He gathered intelligence information for the king in order to prevent sudden attacks from internal and external enemies ${ }^{11}$. In Benin, Chief Ezomo was a replica of Chief Ojomo in Isua. It was one of the members of council of Uzama instituted during the period of Oba Akenzua, 1713-1735. He was a member of the kingmakers, but he was not responsible for selecting the king (Igbafe: p. 5).The title was made to be hereditary. Chief Ezomo performed the functions of checks and balances over the excesses of the king (Edo: p. 4). Added to the above, Chief Ezomo administered his village in line with the Benin kingdom (Igbafe: p. 5). He had more influence over his village for political and economic recognition. In spite of his influence, he had no special control on the army, because there was no standing army under his control (Edo: pp.6-7). Be that as it may, both Chiefs Ojomo and Ezomo belonged to the group of noble chiefs which prevented internal interregnum in the kingdom.

\section{The Table below shows Isua Chieftaincy Titles and their Benin Equivalence}

\begin{tabular}{c|c} 
Isua Chieftaincy Title & Benin Equivalent \\
\hline Chief Olisa & Chief Oliha \\
Chief Osere & Chief Esere \\
Chief Ojomo & Chief Ezomo
\end{tabular}

It is important to mention that the titles are embedded in Isua and Benin chieftaincy structures with corresponding functions. The chiefs performed socio-political functions. Their structure and duties ensured some degree of decentralisation of power. Upon this, Isua people adopted and retained the Benin chieftaincy titles because the quarters in Isua were not large as that of Benin kingdom ${ }^{12}$. The adoption of Benin chieftaincy titles was exceptional in Isua socio-political setting, because among the Benin migrants, chieftaincy

\footnotetext{
${ }^{11}$ Interview held with Alonge Dominina Cited.

${ }^{12}$ Interview with Alonge Dominic cited.
} 
title holders were (and is still) the head of family, and were able to perform both civil and domestic duties in reference to Benin customs. For instance, it was in recognition of Benin tradition of norms and values that was exercised during the celebration of Igue festival (Saba, ed. P. 9). This suggests strong historical connection and cultural affinity of Isua people with the people of Benin kingdom in the earliest period. Against this background, Isua chieftaincy system and culture showed that the Benin immigrants came with? the identified three chieftaincy titles from their original home in Benin kingdom to their new settlement in Isua, due to imposition of supremacy.

Also, it was not possible to shed off original culture being part of life through acculturation and socialisation. There are certain aspects of Benin culture, such as language, folklores, among others, that cannot be forgotten or totally dropped. The chieftaincy titles were re-introduced to reintegrate the mark of Benin culture in Isualand.

\section{A Critique of Benin-Isua Relations}

This section examines Benin-Isua relations on the Benin-Ife connection and its overall effects on Yoruba historiography. There are many contradictions about the evolution and migration of the people of Benin kingdom to the present domain, especially those on the borderline of frontier zone of northeastern Yorubaland, who claimed to have migrated from Ile-Ife. Flowing from this premise, this study observed that Oyolola offered a controversial view about the tradition of origin of the diverse groups of people in Isualand. He discussed the emergence of Isua and its relations with near and far neighbours due to the influence of geographical location that determined their group relations in the area of culture and economic activities.

In his claim for Isua political relations with Benin kingdom, fundamental flaws were discovered, that had no place in Benin history. Oyolola's study of Isua history appears to be full of patriotic sentiments and not investigative in his employed approach to historical study of Isua in precolonial period. The present study partly incorporated this argument with vivid clarification that Benin kingdom also had her historical place in the history of some communities in northeastern Yorubaland. It is in line of this historical relationship (antecedent) that this study has examined and discussed the cultural (chieftaincy institution) influence of Benin on Isua chieftaincy titles.

In pre-colonial period and even beyond, the settlement of Benin migrants in Isua was the outcome of their mass migration from Benin during the earliest period. The migration story filled the gap of the myths and reality of the place of Benin in the 'creation' story. Thus, Isua people can simply be referred to as the mainstream of Benin stock that evolved into mini-states during the state formation, rather than being the rise of Benin to a great kingdom. In spite of the dangers inherent in the works of some nationalist 
historians on Benin studies, for instance, Ife (Uhe) is still used for greetings in the palace of $O b a$ of Benin ${ }^{13}$. It was a symbol of unity and integration for state building.

Indeed, this study has demonstrated the 'pride' of Benin kingdom on the Isua chieftaincy titles, as a result of her historical influence on sociopolitical affairs of Isua community in pre-colonial period. It was in that direction that $\mathrm{Oba}$ Erediauwa, for instance, reiterated how the presence of Oranmiyan in Benin kingdom became a historical spontaneity. For instance, Ife or Ife Ode still referred to the place where land spread to other places in Yorubaland, forest kingdom of West Africa up to Ghana, including Benin (was and is still) significant in Yoruba historiography (Erediuwa: pp. 207 212, Adediran: p. 114, Available: htt://jimidisu..... \& The Nation, 2015: p. $3)$. Isua and Benin chieftaincy relationship is contextual issue in historical writings. From the available evidence, Isua's assertion on progenitor from Oduduwa ancestry in the forest region of Yorubaland was a factor that can still be subjected to historical inquiry among the Benin splinter group, between $12^{\text {th }}$ and $14^{\text {th }}$ centuries (Akomolafe: 1976).

\section{Conclusion}

From the foregoing, it has been established that Isua adopted chieftaincy tradition and the culture of Benin immigrants led by Prince Innih. In relation to that, the study found out that the people of Isua are more of Edo speaking (people), except Osumu and Upala groups that were direct migrants from Ile-Ife and the autochthones in Isualand as it was usually revealed during the celebration of Ogunme festival ${ }^{14}$. Thus, Edo culture took over the process of Yorubanisation in Isua after Prince Innih had consolidated himself on the throne with centralisation of political chieftaincy titles from the family unit. It is historically incongruent to mention that in-depth investigation into the history of bordered towns and villages, especially in the forest zone of Yorubaland, has been done. However, contradictions dotted relative historical facts that were portrayed by different scholars.

Subsisting is Adedeji's observation on these shortcomings, he observed that "historical explanations like all forms of exploration opened up, new and often, rewarding areas of discourse and interrogation" (Nigerian Tribune, 2004: 8). In reappraising his observation, this study has discussed the Benin chronological influence on the identified Isua chieftaincy titles from

$13 \mathrm{htt} / /$ jimidisu.com/kabiyesi-okunade-sijuwade-waja-erin-wo-ajanaku. . . 10/19/2015; 11:31AM, 3 of 17. The Nation, August 20, 2015, 3.

${ }^{14}$ Interview held with Dr Cyril cited. 
historical perspective ${ }^{15}$. Similarly, the study has succeeded in exploring Benin influence on Isua chieftaincy titles. The study pointed out the impact of 'cultural adaptation' on Isua chieftaincy titles, which further reinforced postadoption of similarities that linked the people of Isua with Benin kingdom.

The historical evolution and trend of Benin history was stampeded by the sudden appearance of Oranmiyan to rule Benin kingdom. Nevertheless, the circumstance was a phase in Benin history that has caused confusion and hot debates as to where Benin came from, and her position in the history of Yoruba. It is then inferred that little is yet clear about the earliest history of Isua and its relations with Benin kingdom. There is still subject of investigation into Isua history, being a pre-literate people or groups with no written records kept to make a correspond re-interpretation of historical facts. On this note, Isua early history of origin mainly relied on eye-witnesses description. In that respect, Benin legacy on Isua chieftaincy titles cannot be displaced in the annals of Benin studies, as this study was able to point out that in pre-colonial period, the historical presence and fecundity in Isua (Yoruba) historiography cannot be dismissed.

\section{References:}

1. Adediran, 'Biodun. (1989) "In Search of Identity?: The Eastern Yoruba and the Oduduwa Traditions". ODU: A Journal of West African Studies, p. 36

2. Ajayi, J.F.A.\& Crowder, M. (1971) History of West Africa, vol. l, Ibadan: Longman Groups Limited.

3. Akintoye, S. A. Revolution and Power Politics in Yorubaland $1840-$ 1893: Ibadan Expansion and the Rise of Ekiti Parapo. London: Longman Group Limited, 1971

4. . (1969) "The North-East Yoruba Districts and the Benin kingdom". Journal of Historical Society of Nigeria (JHSN), 4, 4.

5. Akinruntan, F.E.O. (2016) A History of the Oldest Traditional Throne in Yorubaland, Ilaje: Oba Akinruntan Center for Cultural Studies.

6. Akomolafe, C.O. (1976) "Akoko under British Rule., 1900-1935". Unpublished M.phil. degree, University of Ife, Ile-Ife.

7. Beeley, J. H. (1932) CSO 26/2, File No. 29667. "Intelligence Report on Akoko District". Owo Division.

8. Edo, V. O. (2001). "The Benin Monarchy, 1897-1978: A Study in Institutional Adaptation to Change," unpublished Ph.D Thesis, University of Ibadan.

15 For more details, see http://jimidisu.com/kabiyesi-Okunade-sijuwade-waja-erin-woajanaku - sun bi oke (1) . . . 19/10/2015, 11:31 am, 2 \& Adediran, "In Search of Identity?: . . ., 114 . 
9. Eghraevba, J. U. (1968) A Short History of Benin. Ibadan: Ibadan University Press.

10. Erediauwa, Omo N'Oba N'edo. (2003). I Remain Sir, Your Obedient Servant. Ibadan: Spectrum Book Limited.

11. Forde, D and Kabbery P. M. Eds. (1967) West African Kingdom in the Nineteenth Century. London: Oxford University press.

12. Igbafe, P. A. (1979) Benin under British Administration. London: Longman Group Limited.

13. Ilesanmi, O. O. (1964) "Population and Settlement Pattern in Akoko". Unpublished B. A. Project, University of Nsukka.

14. Lloyd, P.C. (1962) Yoruba Law. NISER, Oxford University press Nigerian Tribune, 28 October, 2004.

15. Ogidan, S. K. (2013) Isua Past and Present, Lagos: Datanimic Press.

16. Oguntomisin, G. O., (2006) Political Systems of Nigerian Peoples up to 1900. Ibadan: John Archers (Publishers) Ltd..

17. Ojo, Olatunji, (2003) "Warfare, Slavery, and the Transformation of Eastern Yorubaland C. 1820 - 1900", unpublished Ph.D. Thesis, York University, Toronto, Ontario.

18. Olomola, I. O. (1978 \& 1979) "How Realistic are the Historical Claims of Affinity among the Yorubas?" 1978/1979, Seminar History papers, University of Ife, Ile-Ife.

19. Olukoju, Ayodeji, et.al. (2003) Northeast Yorubaland: Studies in the History and Culture of a Frontier Zone. Ibadan: Rex Charles publications.

20. Ondo State of Nigeria, ( 1999) Report of the Ondo State Judicial Commission of Inquiry on Chieftaincy Matters comprising Chieftaincy Declaration, Paramoutcy, Prescribed and Consenting Authority. Part II, January.

21. Oyolola, E. A., (2010) The History of Isua Akoko and Its Dynasty. Lagos: CSS Bookshop Ltd, 2010.

22. Smailes, A. E. (1953) The Geography of Towns. London.

23. The Declaration of White Paper II of Morgan Commission, 1978 and 1981.

24. The Nation, August 20, 2015.

25. Western State of Nigeria; Western State Chieftaincy DeclarationAkoko Division, Ministry of Local Government and Chieftaincy Affairs, Ibadan: Government Printers, 975/ 1170/500.

26. Available: http://jimidisu.com/kabiyesi-Okunade-sijuwade-waja-erinwo-ajanaku - sun bi oke (1) . . . 19/10/2015, 11:31am, p. 2.

27. http://www.Yorku.ca/nhp/seminars/2003_papers./ http://www.goggle.com/searc?,14.

28. Agbailu, Eunice, Oral Interview, June 5, 2018. 
29. Ajiboro, J.A. June 5, 2018.

30. Ajulo, Oriafe, Oral Interview, April 10, 2016.

31. Alonge Dominics (the Atunluse of Isualand), Oral Interview, April 10, 2016.

32. Mary Cyril, Oral Interview, July 5, 2018.

33. Olugbemi, V.K., Oral Interview, February 9, 2017. 